Society, Culture and the Auditory Imagination in Modern France 
This page intentionally left blank 


\section{Society, Culture and the Auditory Imagination in Modern France}

The Humanity of Hearing

Ingrid Sykes

Research Fellow, La Trobe University, Australia 


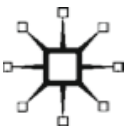

(C) Ingrid Sykes 2015

Softcover reprint of the hardcover 1st edition 2015 978-1-137-45534-5

All rights reserved. No reproduction, copy or transmission of this publication may be made without written permission.

No portion of this publication may be reproduced, copied or transmitted save with written permission or in accordance with the provisions of the Copyright, Designs and Patents Act 1988, or under the terms of any licence permitting limited copying issued by the Copyright Licensing Agency, Saffron House, 6-10 Kirby Street, London EC1N 8TS.

Any person who does any unauthorized act in relation to this publication may be liable to criminal prosecution and civil claims for damages.

The author has asserted her right to be identified as the author of this work in accordance with the Copyright, Designs and Patents Act 1988.

First published 2015 by

PALGRAVE MACMILLAN

Palgrave Macmillan in the UK is an imprint of Macmillan Publishers Limited, registered in England, company number 785998, of Houndmills, Basingstoke, Hampshire RG21 6XS.

Palgrave Macmillan in the US is a division of St Martin's Press LLC, 175 Fifth Avenue, New York, NY 10010.

Palgrave Macmillan is the global academic imprint of the above companies and has companies and representatives throughout the world.

Palgrave ${ }^{\circledR}$ and Macmillan ${ }^{\circledR}$ are registered trademarks in the United States, the United Kingdom, Europe and other countries.

\section{ISBN 978-1-349-49813-0ＩSBN 978-1-137-45535-2 (eBook) DOI $10.1057 / 9781137455352$}

This book is printed on paper suitable for recycling and made from fully managed and sustained forest sources. Logging, pulping and manufacturing processes are expected to conform to the environmental regulations of the country of origin.

A catalogue record for this book is available from the British Library.

Library of Congress Cataloging-in-Publication Data

Sykes, Ingrid.

Society, culture and the auditory imagination in modern France : the humanity of hearing / Ingrid Sykes.

pages $\mathrm{cm}$

Summary: "This book examines the striking way in which medical and scientific work on hearing in eighteenth and nineteenth-century France helped to shape modern French society and culture. Contemporary scientists and anatomists had to come to terms with a new kind of transformative physiology within the material site of the human ear, one that had the potential to construct space and place in the most powerful way imaginable. Auditory medical specialists found themselves at the center of pivotal philosophical, political and social debates on how the individual citizen might use their ears to reach out to those around them constructing broader, protective models of social reform. Sykes makes the case that of all the senses, hearing offered the greatest resources for remodelling the idea of the universal human condition within the modern French historical setting" — Provided by publisher.

1. France-Civilization. 2. National characteristics, French. 3. France-Social life and customs. 4. Auditory perception. 5. Listening-Social aspectsHistory. 6. Listening-Political aspects-History. 7. Listening-Psychological aspects-History. 8. Physicians-France-Attitudes-History. 9. JudgesFrance-Attitudes-History. 10. Empathy. I. Title.

DC33.8.S95 2014

944-dc23 


\section{Contents}

List of Figures vi

Preface vii

Acknowledgements $\quad$ x

$\begin{array}{ll}\text { Introduction } & 1\end{array}$

1 Medicine, Science and the Auditory Imagination 15

2 The Juge-Auditeur and Hearing the People 38

3 Hearing and Spaces of Medical Care 50

4 The Blind and the Communication-Object 71

5 Sound, Health and the Auditory Body-Politic 91

$\begin{array}{ll}\text { Conclusion } & 111\end{array}$

$\begin{array}{ll}\text { Notes } & 122\end{array}$

Bibliography 153

$\begin{array}{lr}\text { Index } & 164\end{array}$ 


\section{Figures}

1.1 Joseph Guichard Duverney, Traité de l'organe de l'ouïe, planche III (Paris: Estienne Michallet, 1683). BIU Santé, Paris

1.2 Joseph Guichard Duverney, Traité de l'organe de l'ouïe, planche VII (Paris: Estienne Michallet, 1683). BIU Santé, Paris

1.3 Joseph Guichard Duverney, Traité de l'organe de l'ouïe, planche XVI (Paris: Estienne Michallet, 1683). BIU Santé, Paris

3.1 François-Nicolas Marquet, Nouvelle méthode facile et curieuse pour connaître le pouls par les notes de la musique, 2nd edn (Paris: Didot le Jeune, 1769), extract. Wellcome Library, London

4.1 Épreuves des caractères des Aveugles, gravés et fondues pour être imprimés en relief, par Vafflard graveur-fondeur en Caractères d'Imprimerie, Cloître Notre-Dame, 7, inv. B-10-5003. Musée Valentin Haüy, Paris

4.2 Valentin Haüy, "Résumé des Principes Généraux de la Lecture, Tableau 1 et Tableau 2," Nouveau syllabaire... manuel de l'élève [et manuel de l'instituteur], par le citoyen Hauy (Paris: Institut national des aveugles travailleurs, an VIII [1799-1800]). Bibliothèque Nationale de France, Paris

5.1 Jean-François Salomon, Original patent manuscript, Brevet d'invention de 5 ans, instrument de musique, appelé par l'auteur Harpo-Lyre (Paris, 1829), Cote du dossier: 1BA3120. Archives INPI, Paris 


\section{Preface}

Tracing a history of hearing is not straightforward. It requires that we consider not simply the sounds or sonic fields of the past but the broader imaginative models that hearing encompassed at that particular time and place. Throughout French modern history, hearing was a fundamental part of the way in which humans thought about themselves and those around them. Embedded within its meaning was not simply the activation of a specific physiological human "sense" but a specific stance or posture that caused the redefinition and reshaping of social, political and cultural boundaries and their spaces. Hearing, from this perspective, went well beyond auditory languages and landscapes of information to encompass those discourses and spheres emphasizing critical forms of social and political care and protection: the courtroom, the hospital and the disabled schoolroom. Hearing might involve hearing actual sounds in these places, but it was not ultimately dependent on them. Rather, hearing in these sites primarily occurred through the positive activation of the human imagination.

Implicit in the imaginative hearing model was a paradox - a crisis, perhaps - that positioned the individual at the crossroads of their own individual sense of self and the collective social sphere. How can we exist as ourselves whilst coexisting with others at the same time? Yet hearing offered powerful resources in resolving this paradox. To hear was to confront the fragile edges of the self and in turn free one from oneself to forge a positive relationship with others. It is easy to overlook such a radical self/subject framework. Indeed, as we rely increasingly on subjective experience, abstract pools of information and the visual field, hearing, aside from acting as a basic mode of cognition, appears almost obsolete. Yet in recent public and scholarly discourse, particularly in the medical and public health field, consideration for hearing and listening in this more deep, holistic sense is gaining ground. Doctors are now asked, for example, to listen more carefully to patients. Alternative medicine is gaining mainstream recognition. Modern medical practice involves not only thinking about a patient's problem but also imagining how they might feel and acting appropriately. There is an increasing sense that, without evidence of a sophisticated hearing stance, the modern medical industry cannot purport to care for people or understand their needs. 
This book brings the historical narrative of this hearing stance into greater focus. It reveals that hearing in France played a formative role in shaping modern society as we know it today. Significantly, the book focuses a great deal on the role of medicine within this process. Just like medical practitioners today, those in French modern history were concerned with how they were hearing their patients. The collision of medical otology and French philosophy during the Enlightenment initially forced hearing as an empathetic social practice into the public domain. Prior to the revolution, the French élite again consolidated hearing's presence at the forefront of social change by envisaging radical spaces of hearing, such as the medical clinic, the courtroom and the modern hospital. They reinforced the broader political message that the people must be heard. During the post-revolutionary period, the body, as a whole, took on a hearing stance. The auditory body was a dynamic hearing posture in which the individual self could attach itself to a collective form of state care. Technologies became increasingly important in this listening act, fixing the individual listener to his/her own intimate communicative framework.

To study such a history of hearing is not to undermine the significance of music, art or science, disciplines which intersect with hearing in important ways. Rather, it is to reinterpret and highlight these disciplines and their languages as key tools in contributing to a more powerful social metalanguage that had the capacity to create change entirely on its own. Significantly, medical and judicial institutions, where techniques and practices of hearing were most evident, became central in channelling and shaping this agenda. In the clinic, pulse theories reinvented musical idioms in order to connect patient to doctor. Industrial materials fashioned linguistic devices so that the blind could hear messages of belonging in their own institutional spaces. The modern hospital and the small claims courtroom emerged as one of the most sensitive listening sites. This was where the cry of "humanity" was loudest and most intense.

This book does not chart a straightforward chronological history. It suggests through a variety of case studies the ways in which hearing might have shaped modern French society from the Enlightenment to the modern industrial age at its deepest level. Hearing becomes an open and closed mode of topographical analysis, an anthropological tool for uncovering relational patterns which became set in the landscape to form our modern, social settings. Such a process of activity, like hearing itself, was inherently dynamic. Shifting voices created shifting spaces which might succeed or fail. The French Revolution can be interpreted 
as a heightened point of intensity in society's hearing flow. It represents the fragile point in the hearing process where perceptual gambling had to begin. The crisis of the "false noise" consumed the entire social and political setting for a considerable period of time until the hearing process could resume and the social setting stabilize. Hearing as a positive practice in constructing human relationships has continued to feature as a key defining cultural, political and social force within the modern world. 


\section{Acknowledgements}

I extend my special thanks to Holly Tyler at Palgrave Macmillan for bravely taking on this project for publication. This book could not have been completed without the support of a major research fellowship from the Wellcome Trust, UK. The Centre for the History of Medicine, University of Warwick, UK, generously hosted this fellowship and supported my research ideas from the very beginnings of the proposal process through to publication and completion.

Thank you also to Daniel Pressnitzer of the Equipe Audition, Laboratoire Systèmes Perceptifs, Ecole Normale Supérieure, Paris. His highly imaginative work on auditory scene analysis, which he presented as a keynote at my 2009 Warwick international symposium, "Signalling Sound", helped facilitate key conceptual shifts in my thinking that led to the formation of this work. Another important individual whom I must thank is Penelope Gouk, who shared her expertise with me during this lengthy research period in such a warm, generous and spirited fashion. Her enormous breadth of knowledge on seventeenthand eighteenth-century European sound culture as well as her skill in analysing medical treatises from this period has influenced my writing and thinking on this topic in a profound and lasting way. To those who read my drafts and provided valuable input, Ian Coller, Daniel Grimley Ida Nursoo, Susan Sykes and the highly intuitive students from my 2013 La Trobe University Honours Group, "History and the Human Condition" - thank you all for your helpful insights and comments on my work.

This work was supported by the Wellcome Trust, UK (75002). 